\title{
论 文 中国植被生态学专辑
}

\section{海南植被分类体系与植被分布图}

\author{
杨小波 ${ }^{1 *}$, 陈宗铸 ${ }^{1,2}$, 李东海 ${ }^{1}$
}

1. 海南大学生态与环境学院, 海口 570028 ;

2. 海南省林业科学研究院, 海口 571199

*联系人, E-mail: yanfengxb@163.com

收稿日期: 2020-08-18; 接受日期: 2020-11-26; 网络版发表日期: 2021-01-05

国家重点研发计划(批准号: 2016YFC0503100)和国家自然科学基金(批准号: 31760170)资助

摘要 本文结合历史资料和本团队30多年的野外样方调查数据, 分析了海南植被的组成与结构特点, 修订和完善 了海南植被分类体系; 通过遥感解译、样方数据和野外实地核实, 完成了海南植被分布图的绘制. 在水平地带性 上, 海南植被可区划为热带雨林区和季雨林区. 在热带雨林区, 垂直地带上可区划为低地雨林、山地雨林、高山 云雾林和山顶灌丛; 在季雨林区, 植被类型垂直地带性差异不明显. 非地带性植被类型有海草床(草丛)、红树林、 滨海丛林，包括潟湖、岛屿和河口等海岸丛林(含三沙市的岛屿丛林)、滨江(河)丛林、次生草丛、次生灌丛和藤 蔓丛等.海南植被可划分为自然植被和人工植被两大类，自然植被可分为森林、灌丛、草丛和藤䕊丛 4 个植被型 纲, 5 个植被型组, 14 个植被型, 196 个群系(“群系” 《《海南植被志》中的“类群”); 人工植被主要有 3 个植被型组: 生 态保护植被型组、生态景观植被型组和农业生产植被型组, 共9个植被型. 本研究同时完成了海南省尺度(不含三 沙市)、市县尺度和乡镇尺度等三个级别的分布图(1:5万比例尺).

关键词植被分类, 热带植被, 海南, 中国, 植被制图

亚洲的热带雨林，多以龙脑香科(Dipterocarpaceae)、肉豆冦科(Myristacaceae)、玉荵科(Barringtoniaceae) 等种类为优势 ${ }^{[1,2]}$. 中国的雨林由于分布于热 带北缘，典型的热带种已较少，如龙脑香科植物在东 南亚约有 25 属 400 余种, 在中国只有 5 属和 12 种 ${ }^{[3]}$, 其中 海南只有2属3种, 云南和广西南部有4属 6 种 ${ }^{[3]}$. 但是, 龙脑香科、肉豆冦科、玉荵科等科植物的出现，也说 明中国雨林与东南亚赤道雨林有密切关系，属亚洲热 带雨林范畴 ${ }^{[3 \sim 12]}$.

热带季雨林一直以来都是颇具争议的植被类型,
国内外不同的学者使用的名称并不一致. Beard ${ }^{[13]}$ 在研 究南美洲的特里尼达岛热带森林时, 将其划分为低山 雨林、常绿季雨林、半常绿季节雨林和落叶季节林四 个顶极类型. 而Richards ${ }^{[1]}$ 认为, 这个方案中的常绿季 节林和低山雨林在群落结构和外貌上差异很小，应该 把常绿季节林归并到热带雨林的范畴. 热带季雨林的 物种丰富度由于不同地区不同学者所选取的样地面积 不同而无法比较, 但是其相对热带雨林来说是较低的, 且优势种和主要伴生种在干旱季节落叶是热带季雨林 的典型特征 ${ }^{[14 ~ 17]}$. 在海南的落叶季雨林中, 其优势种

引用格式: 杨小波, 陈宗铸, 李东海. 海南植被分类体系与植被分布图. 中国科学: 生命科学, 2021, 51: 321-333

Yang X B, Chen Z Z, Li D H. Classification and distribution of vegetation in Hainan, China (in Chinese). Sci Sin Vitae, 2021, 51: 321-333, doi: 10.1360 SSV-2020-0286 
和主要伴生种海南榄仁(Terminalia hainanensis)、厚皮 树(Lannea coromandelica)、木棉(Gossampinus malabarica)、白格(Albizzia procera)和黑格(A. odoratissi$m a)$ 等均为落叶树种, 与热带雨林有显著的差异 ${ }^{[6,12]}$.

Beard $^{[13]}$, Richards ${ }^{[1]}$, Whitmore ${ }^{[2]}$,Webb ${ }^{[18,19]}$ 以及 中国植被编辑委员会 ${ }^{[3]}$ 等分别对美洲热带森林、远东 热带森林、澳大利亚雨林和中国热带森林植被进行 了详细的分类. 国际上, 多从植被结构和外貌的组合 特点确定热带森林不同的群系(formation) ${ }^{[2,20]}$. 但这里 的“formation”是高级分类单位，对应的是《中国植 被》中的植被型 ${ }^{[3]}$, 而《中国植被》中的的群系(formation)是中级单位. 如何结合中国人用语习惯，选用 合适的描述热带雨林中级单位的术语, 还有待于探讨. 另外，虽然世界上的自然植被类型多样，名称也五花 八门，但总体上，低纬度范围内水平地带性分布的植 被类型主要分为热带雨林、季雨林、热带草原(稀树 草原)和热带荒漠，在热带雨林气候区的垂直地带性 植被分为低地雨林、山地雨林、高山矮林(云雾林)和 山顶灌从等已被广泛接受. 海南的植被类型是否能统 一到大家接受的植被分类体系中，本文将进行这方面 的尝试.

另外, 绘制高分辨率的植被分布图十分有必要, 不 仅有利于读者直观认识植被分布规律, 也为科学保护 与利用植被资源提供依据. 但绘制高精度的植被分布 图，在现有技术条件及有限投入的情况下也是非常困 难的. 本文以海南为例, 结合植被分布的特点, 利用多 种技术手段, 开展了这方面的尝试.

\section{1 研究区域和研究资料与方法}

\section{1 研究区域地理简介}

海南省位于中国最南端，北以琼州海峡与广东划 界，西临北部湾与越南相对，东濒中国南海与中国台 湾相望, 东南和南部与菲律宾、文莱和马来西亚为邻. 海南省的行政区域包括海南岛及其周边岛屿、西沙群 岛、中沙群岛、南沙群岛的岛礁及其海域，是全国面 积最大的省. 海南岛位于雷州半岛的南部，地处北纬 $18^{\circ} 10^{\prime} \sim 20^{\circ} 10^{\prime}$, 东经 $108^{\circ} 37^{\prime} \sim 111^{\circ} 03^{\prime}$ ，长约 $290 \mathrm{~km}$ ，西 北至东南宽约 $180 \mathrm{~km}$, 总面积(不包括卫星岛)约 33900 $\mathrm{km}^{2}$. 海南岛四周低平, 中间高䇯, 呈穹隆山地形, 以五 指山、鹦哥岭为隆起核心, 向外围逐级下降, 由山地、
丘陵、台地、平原构成环形层状地貌，梯级结构明显. 山地和丘陵是海南岛地貌的主要特征，占全岛面积的 $38.7 \%$. 山地主要分布在岛中部偏南地区. 比较大的河 流大都发源于中部山区, 组成辐射状水系. 全岛独流入 海的河流共154条，其中集水面积超过 $100 \mathrm{~km}^{2}$ 的有 38条.

海南岛地处北回归线以南的热带北缘，属热带季 风气候区, 年平均气温 $22 \sim 27^{\circ} \mathrm{C}$, 大于或等于 $10^{\circ} \mathrm{C}$ 的积 温为 $8200^{\circ} \mathrm{C}$, 最冷的 1 月温度仍达 $17 \sim 24^{\circ} \mathrm{C}$. 雨量充沛, 年降雨量在1000 2600 mm, 年平均降雨量为 $1639 \mathrm{~mm}$, 有明显的多雨季和少雨季. 雨季降水约占年降雨量的 $80 \%$. 东部多雨区降雨量2000 2400 mm，最高可达 $2600 \mathrm{~mm}$; 西部少雨区降雨量仅 $1000 \mathrm{~mm}$ 左右.

海南岛的土壤成土母质岩有花岗岩、玄武岩、火 山灰等多种。主要土壤类型有砖红壤, 面积为 $181.5 \times 10^{4} \mathrm{hm}^{2}$ ，全岛都有分布，占陆地总面积的 $51.26 \%$; 赤红壤总面积有 $34 \times 10^{4} \mathrm{hm}^{2}$, 约占陆地面积的 $9.6 \%$. 在东部海拔 $700 \mathrm{~m}$ 以上，西南海拔 $800 \mathrm{~m}$ 以上的 山地上, 土壤受水化作用影响, 出现黄壤. 另外, 海南 还分布有燥红壤、新积土、滨海沙土、石灰(岩)土、 火山灰土、紫色土、石质土、沼泽土、滨海盐土、酸 性硫酸盐土、水稻土、山地草甸土和珊瑚沙土等类 型 ${ }^{[21 ~ 26]}$.

\section{2 研究方法}

（1）遥感解译方法. 采用高分辨率遥感影像, 经校 正、融合、增强，结合研究区自然地理资料及大量的 样地数据分析, 开展植被类型的解译与区划, 最后采 用实地调查与验证，建立全岛Geodatabase格式的植被 覆盖地理信息数据库, 在ArcGIS下完成制图.

（2）野外核实法. 野外核实方法主要是路线调查 和样方调查相结合的方法. 样方有固定样方和临时样 方两种形式，样方大小有 $400 \mathrm{~m}^{2}$ 到 $2.56 \mathrm{hm}^{2}$ 不等，总面 积超过 $100 \mathrm{hm}^{2}$. 样方选择几乎覆盖海南所有植被类型 (图1). 特别是在垂直取样方面，在海南最有代表性的 山体上，采用海拔每上升 $100 \mathrm{~m}$ 做至少 4 个 $10 \mathrm{~m} \times 10 \mathrm{~m}$ 的样方. 样方内记录方式采用每木(树高达 $1.5 \mathrm{~m}$ 的个 体都测量)记录胸径、树高和冠幅或记录调查目的种 的胸径、树高和冠幅等. 植物组成区系分析采用吴征 篮 ${ }^{[27]}$ 的分析方法，植物群落结构与组成分析方法采用 王伯称 ${ }^{[28]}$ 的传统植物群落分析方法. 


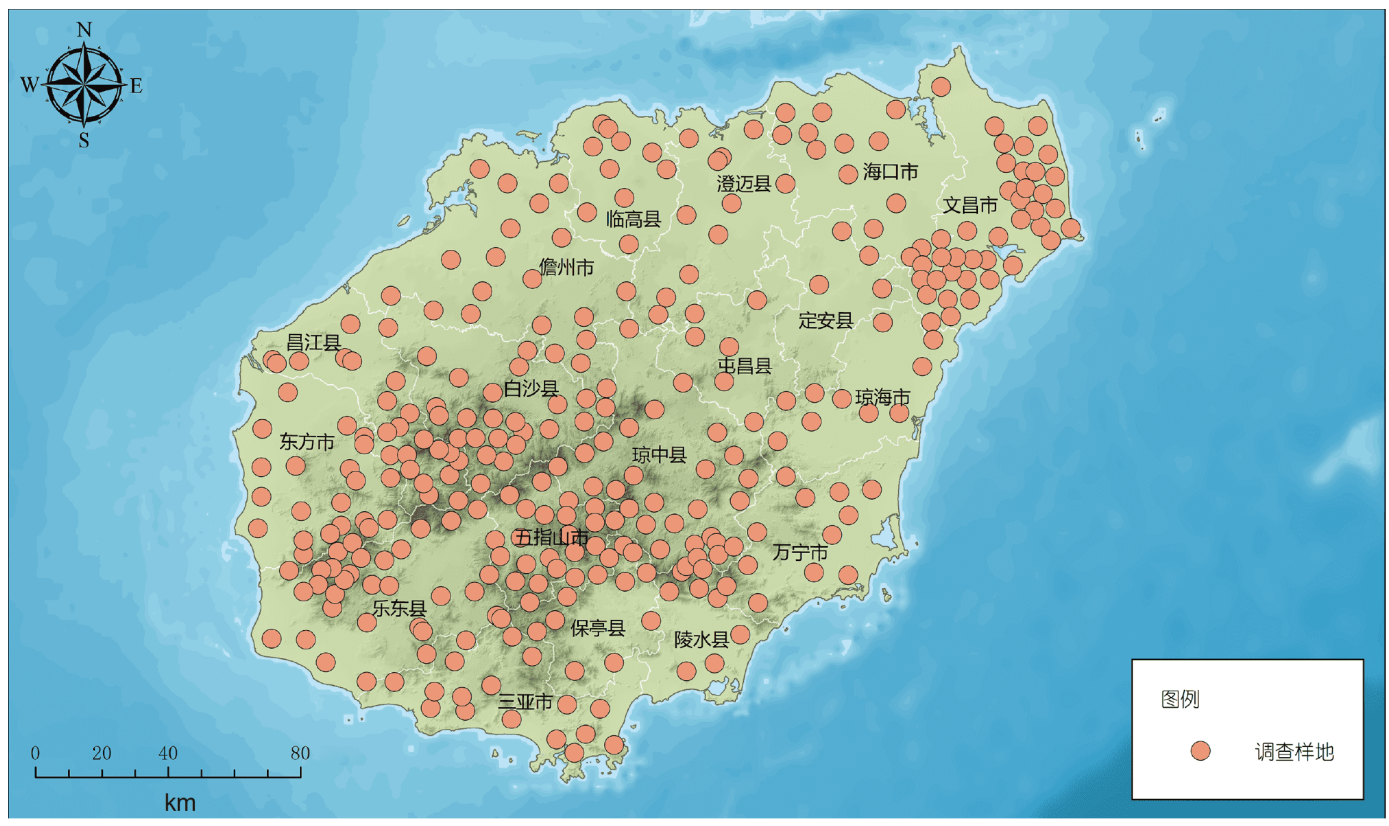

图 1 海南岛植被调查样方点分布图

Figure 1 Distribution of plots for vegetation survey conducted in this study in Hainan Island

\section{2 结果与分析}

\section{1 海南植被的区划}

结合海南岛的水热(图2, 图例为干燥度)、地形(图 3)与土壤等生态环境因素, 在充分分析各样地植物组 成与结构的基础上，不考虑非地带性植被中的红树 林、滨海从林、滨河从林、灌从及草丛等. 海南的水 平地带性植被的分布区可划分为热带雨林区(含季雨 林与雨林过渡类型)、季雨林区两大区域(图4).

热带雨林与季雨林的分界线大致从昌江县沿海的 海尾镇进董村一带开始(过渡带可北到该镇的梧高村 一带，东北为热带雨林分布区，西南为季雨林分布区， 下同), 经荔枝岭南侧、金牛岭、俄牙岭，最后经七差 镇的燕窝岭一带进入东方市; 在东方市境内经金炳 村、大广坝水库中部、麦麻岭、独岭的西侧一带进入 乐东县; 在乐东县境内, 经尖峰岭西北和西南外侧、大 岭、长岭、温仁村、牛拉岭一带进入三亚市; 在三亚 市境内, 经天指岭、牛睡岭、高岭后直到六道岭一带. 然后, 再结合地质、地形的变化情况及特殊性, 可在热 带雨林区、季雨林区内划分出滨海从林区及河漫滩与 河岸、火山岩植被分布区及河口淤泥红树林分布区 等; 在热带雨林区, 海南的垂直地带性植被类型可以五
指山地区为代表，划分为低地雨林、山地雨林、高山 云雾林及山顶灌从垂直植被分布带.

\section{2 海南植被分类原则}

海南的植被分类原则遵循在中国已经应用了 30 多 年的, 被中国大多数人所接受的基本原则, 即高级单位 采用生态-外貌原则, 中低级单位采用种类组成, 在种类 组成中兼顾优势种、特征种或标志种的作用. 中级单位 以优势种为主, 低级单位更重视特征种或标志种 ${ }^{[3,29 \sim 31]}$.

《中国植被》主要依据植物组成的物候形态特点 把中国的灌从划分为常绿针叶灌从、常绿革叶灌从、 落叶阔叶灌从、常绿阔叶灌从和灌草丛五大类. 如果 依据《中国植被》的方法，海南仅有常绿阔叶灌从和 灌草丛两大类. 但实际上，海南的常绿阔叶灌从和灌 草丛很难区分，特别是灌丛多是从森林被砍伐后发育 而来, 灌木与草本植物多混生一起. 因此, 本文把灌木 为主的植物群落称为灌从. 海南的灌从总体上仅对应 了《中国植被》中的一个类型：常绿阔叶灌从. 由于 海南较多的灌从多为热带森林被破坏后形成的次生类 型，原始的灌丛仅分布在高海拔，或相当特殊的环境 中，较少受到人为的破坏. 本文依据灌丛的起源把分 布在海南的灌丛划分为两类，一类是地带性灌从，主 


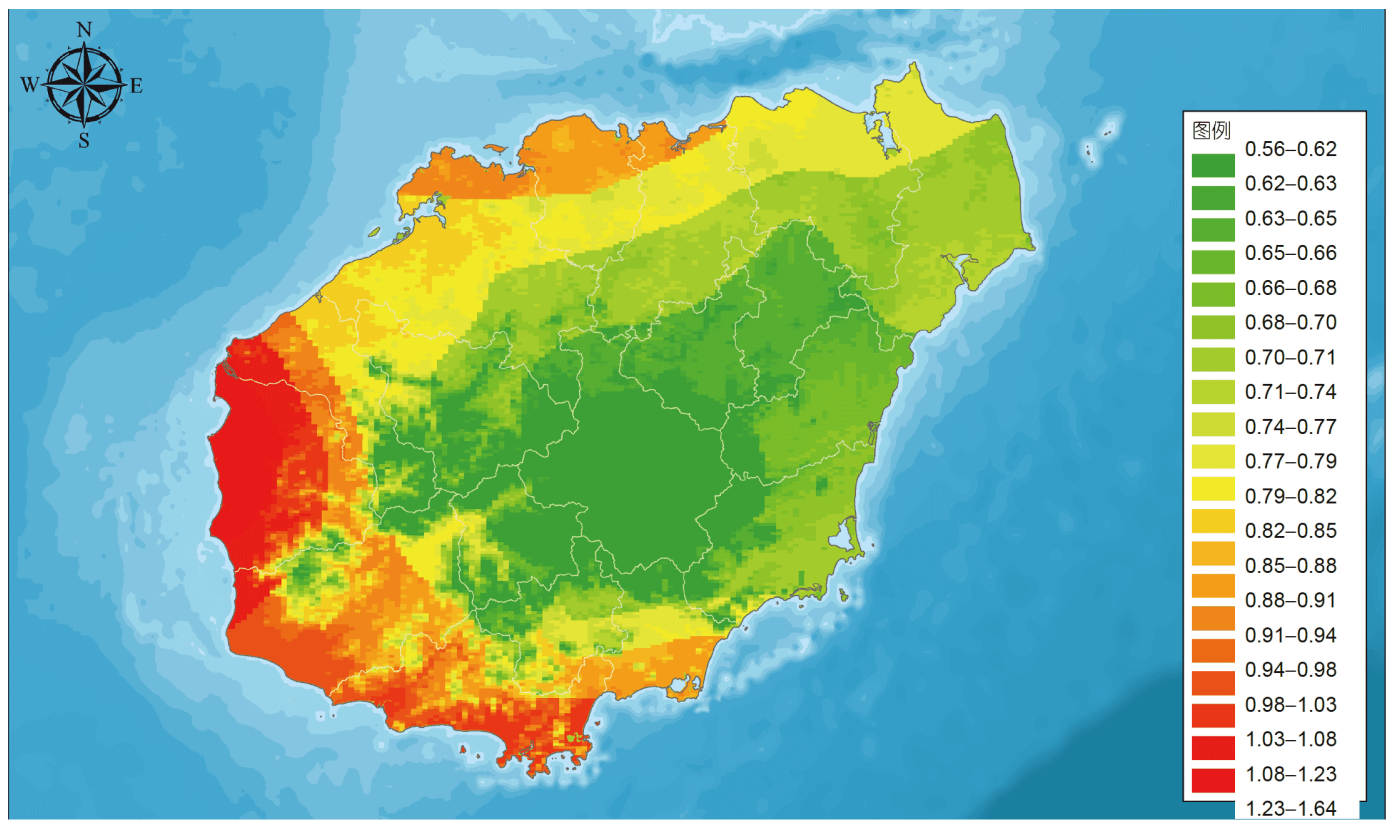

图 2 海南岛干燥度分布图

Figure 2 Distribution of aridity in Hainan Island

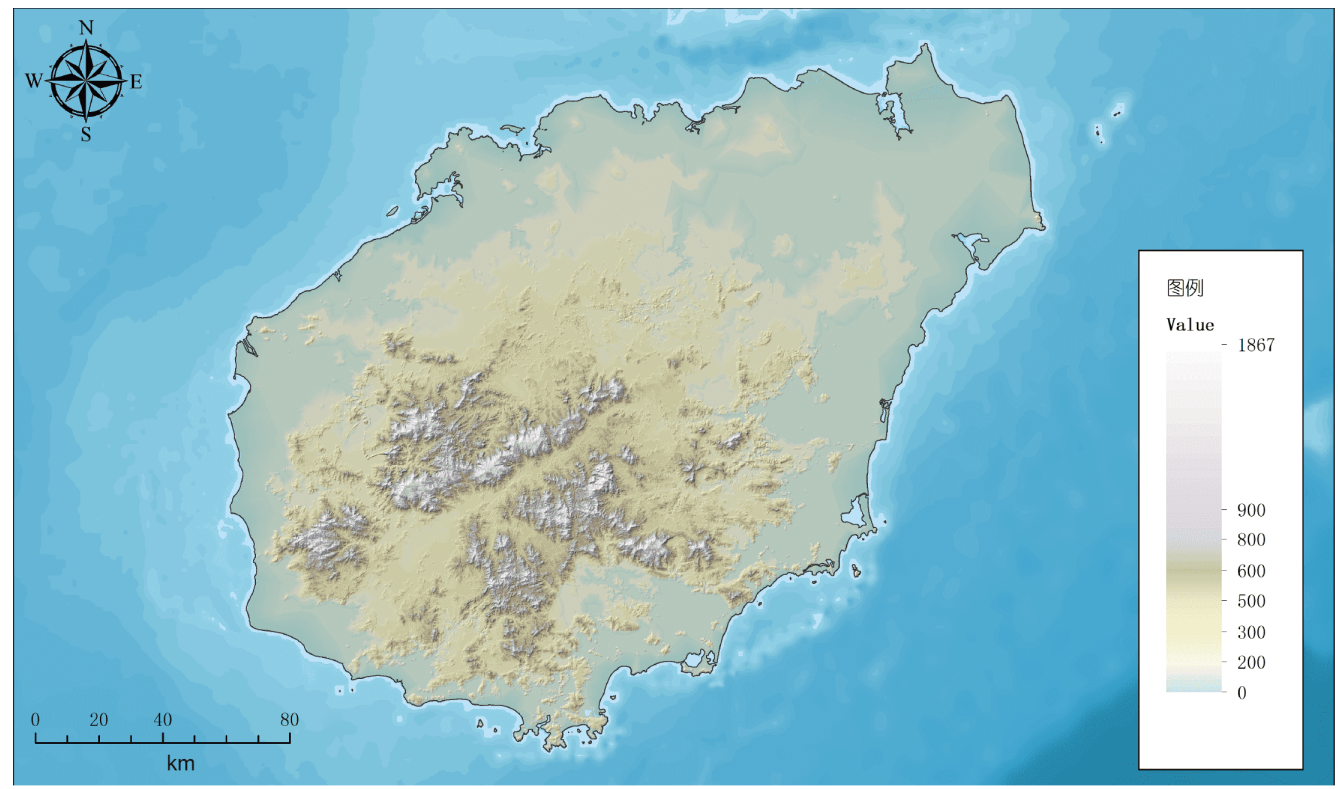

图 3 海南岛地形地貌

Figure 3 Topography of Hainan Island

要包括垂直地带性的山顶灌从(原始类型)和由地带性 森林受破坏后形成的灌丛(次生类型); 另一类是在特 殊环境下发育出来的原始类型，以及森林受破坏后等 特殊环境下发育形成的次生类型。草从的分类也有类
似的情况, 从起源来划分海南的草丛较为方便也较容 易被接受. 但由于海南草丛的来源相对简单，没有草 原和草甸等, 可不设第 II 级分类类型. 另外, 海南海岛 沙滩上的藤本植物群落较特殊, 是单独存在的植物群. 


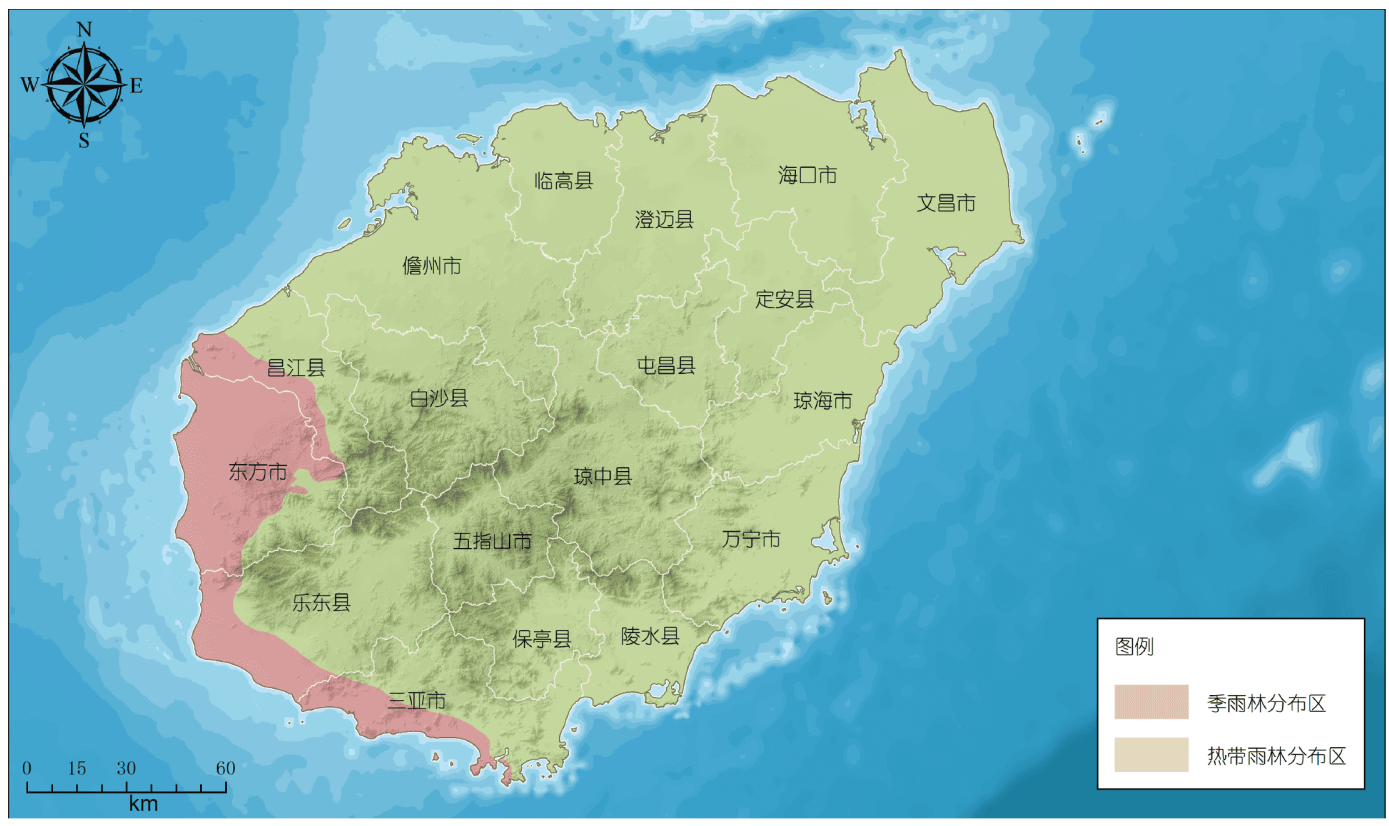

图 4 海南岛地带性植被类型水平分布区

Figure 4 The horizontal distribution of zonal vegetation types in Hainan Island

因此，与森林、灌从和草丛并列, 为单独一大类型, 可 称为“藤蔓从”. 但由于类型相对较少，可不设第 II 级 及 $\mathrm{V}$ 级分类类型. 分布在海岸及河滩上的森林应是在 特殊的土壤类型条件下形成的，属非地带性森林类型， 应与红树林一样分别归为另外两类. 红树林是在海水 淤泥环境中发育形成的丛林，海岸沙滩上的森林为在 咸水沙质土壤环境发育形成的从林，河滩上的森林为 在淡水沙质土壤条件下发育形成的从林．红树林、滨 海(岛屿)沙质从林和滨江沙质从林并列为三种特殊的 非地带性森林. 灌丛、草丛植被也有类似的情况.

在人工植被的分类原则上, 本文认为, 海南所有的 人工植被的形成都有其目的性, 有的是单一性目的, 有 的是以某种目的为主, 多种目的为辅. 因此, 本文认为, 人工植被的高级单位应依据其主要目的来区分，而不 应从形态上来区分. 人工植被主要有如下几种目的: 一是生产物质(食物、纤维、化工原料、药和能源等), 称为“农业生产植被”; 二是生态防护(防风固沙、防水 土流失、防光照射和防冷害等), 称为“生态防护植被”; 三是为景观美学(造景和仿景等), 称为“生态景观植 被”, “生态景观植被”可能含有自然植被、半自然植被 和人工种植的植被. 本文以海南的人工植被为例, 也在 这方面进行了尝试.

\section{3 海南植被分类的单位与名称}

(1) 海南植被分类的单位. 在海南的植被分类单 位中, 高级基本单位采用植被型(与《中国植被》的传 统单位相同，但英文不同，英文为“Vegetation Formation”), 表达一个地区的地带性植被类型或非地带性的 植被类型, 如热带雨林、红树林等; 中级单位采用群系 (与《中国植被》的传统单位的“群系”相同, 但英文不 同, 英文为“Alliance”, 等同《海南植被志》中的“类群 (Group)”), 表达一个地区具体的植物群落组合; 最低级 基本单位采用群丛(《中国植被》的传统单位), 表达 一个地区具体的植物群 ${ }^{[30,32]}$.

(2) 海南植被的分类体系名称解释. 海南的自然 植被类型先按植物的生长型, 如乔木、灌木、草本和 藤本植物及其对极端生境的适应而形成的外貌类型划 分为植被型纲(class of vegetaion type)( I 级); 分别是森 林植被纲、灌从纲、草丛纲和藤蔓丛纲; 在森林、灌 从、草从和藤莫丛的基础上，区分“植被型组(Vegetation Formation Group)"( II 级), 等同《中国植被》 ${ }^{[3]}$ 的 “植被型组(Vegetation Type Group)”和《海南植被 志》 ${ }^{[12]}$ 的“植被亚纲(Sub-Class of Vegetaion type)”; “植 被型(Vegetation Formation)”(III级)等同《中国植 
被》和《海南植被志》的“植被型(Vegetation Type)”, 为植被分类系统中最重要的基础高级单位; “植被亚 型(Vegetation Subformation)”(IV 级)等同《中国植被》 和《海南植被志》的“植被亚型(Sub-Vegetation Type)” 为植被型的辅助单位; 中级单位的群系的集合称为“群 系组(Alliance Group)”(V 级), 等同于《中国植被》的 “群系组(Formation Group)”和《海南植被志》的“类群 集(Collective Group)”; 植被分类系统的基础中级分类 单位仍称“群系(Alliance)”(VI级)，等同于《中国植 被》的“群系(Formation)”和《海南植被志》的“类群 (Group)”; 层片结构相似，优势层片或次优势层片或标 志种相同的植物群落的集合称“群丛组(Association Group)"(VII级)与《中国植被》相同，等同于《海南植 被志》“群丛集(Colletive Association)”, 群丛(Association)(VIII级)为植被分类系统的基础低级分类单位. 表达 一个地理单元具体的植物群落.

\section{4 海南植被类型}

通常热带植被的分类比其他地区的植被分类存在 更大的困难. 热带植被分类的困难, 在某种意义上看是 不同学者在热带植被认识上的问题，是对热带植被分 类原则和方法存在不同看法的问题 ${ }^{[33]}$. 热带地区森林 优势种不明显，一般得通过样方调查计算后，方能分 到群系(Alliance). 经过对历史研究资料的分析与总结 及野外调查核实，结合海南实际，海南植被主要自然 植被与人工植被的分类体系如表 1 所示.

\section{5 植被分布图的制作}

在全面解释遥感影像和对样方数据分析的基础 上, 结合野外调查核实, 尽可能细分各植被类型, 完成 了最新的海南植被分布图. 植被图分辨率达乡镇水平 (比例尺为 $1: 5$ 万). 全岛植被图见图 $5 \mathrm{~A}$, 市县级的植被 图以白沙县为例见图 $5 \mathrm{~B}$, 乡镇级植被图的以白沙县青 松乡为例见图5C. 由于热带多雨地区的自然森林的优 势种不明显, 各植被类型的边界很难区分开, 完成植被 分布图相当困难. 目前的水平, 仅能做到在图中表达山 顶灌丛、针叶林、高山云雾林、山地雨林(以上植被 类型目前保存较好, 较少有次生林)、低地雨林、低地 雨林次生林、季雨林(次生林)(季雨林的原始林和次生 林很难区分)、红树林、丛林(包括滨海(岛屿)沙生性 丛林和滨江沙生性从林)、次生灌从、次生草丛等自
然植被类型的分布情况，人工植被类型主要表达了草 本旱地农业生产植被、木本旱地农业生产植被、水田 农业生产植被、生态防护植被、生态景观植被、农村 聚居地与村庄植被和城市聚居地与景观植被等人工植 被类型.

\section{3 讨论与结论}

较早到海南开展植物调查研究的中国学者是 钟观光先生和陈焕镛先生, 早在19世纪初钟先生和陈 先生就曾在海南开展植物种类调查研究工作. 《海南 植物志》 ${ }^{[34]}$ 曾较详细地描述了海南的植被概况, 这也 是由中国人自己完成的，海南本岛最早的植被概况. 此外, 陆续有不少学者开展海南植物标本采集及植被 生态学研究工作. 较早期(1927 1950年)有曾怀德、冯 钦、李朝贤、刘心祈、高锡朋、梁向日、左景烈、陈 念劬、侯宽昭、黄志、邓良、张宏达等 ${ }^{[12,35]}$. 20 世纪 40 年代, 张宏达 ${ }^{[36]}$ 在详细的西沙植物资源与植被考查 基础上, 完成了《西沙群岛的植被》, 这是中国最早 的地方植被专著之一.

1950年后，朱志松、陈少卿、黄全、钟义、符国 瑗、邢福武等人在海南开展了较详细的植物资源调 查, 为认识海南植被组成及深入开展热带雨林的研究 奠定了基础; 曲仲湘、林英、侯宽昭，徐祥浩、张宏 达、蒋有绪、卢俊培、胡玉佳、胡婉仪、黄全、陈树 培等人则着力研究以热带雨林为核心的海南植被分 类、生态与保育等基础科学问题 ${ }^{[12]}$. 侯宽昭和徐祥 浩 ${ }^{[37]}$ 完成了《海南岛的植物和植被与广东大陆植被 概况》。曲仲湘和林英(1955)为主要负责人完成了 《海南岛植被调查初步总结报告》(内部资料), 该报 告较深入地开展了海南五指山与吊罗山的植被调查工 作，把五指山植被划分为枫香林、萌生林、次生林、 似雨林、半破坏原始林、照叶林、高山矮林和草山草 从. 在此基础上，陆续有不少学者 ${ }^{[3,7,8,28,29,38-45]}$ 从不同 角度开展海南热带森林植被分类研究，为海南森林植 被的科学分类做出了较大的贡献. 此外, 侯学暗的 《中国的植被》 ${ }^{[46]}$, 广东省植物研究所《广东植 被》 ${ }^{[39]}$, 中国植被编辑委员会的《中国植被》 ${ }^{[3]}$, 广东 森林编辑委员会的《广东森林》 ${ }^{[47]}$ 以及中国森林编 辑委员会的《中国森林》 (第三卷 $)^{[48]}$ 等专著都专门论 述了海南岛热带森林的类型及其分类系统. 
表 1 海南植被主要自然植被与人工植被的分类体系

Table 1 Classification system of the main natural and artificial vegetation in Hainan

\begin{tabular}{|c|c|c|c|c|}
\hline \multirow{2}{*}{ 植被分类 } & \multicolumn{4}{|c|}{ 分类体系 } \\
\hline & I 级(植被型纲) & II 级(植被型组) & III级(植被型) & IV 级(植被亚型) \\
\hline \multirow{14}{*}{ 自然植被 } & \multirow{8}{*}{ 森林 } & 针叶林 & 热带性针叶林 & 山地针叶林 \\
\hline & & \multirow{7}{*}{ 阔叶林 } & 热带雨林 & $\begin{array}{l}\text { 低地雨林 } \\
\text { 山地雨林 }\end{array}$ \\
\hline & & & 季雨林 & $\begin{array}{l}\text { 落叶季雨林 } \\
\text { 半落叶季雨林 }\end{array}$ \\
\hline & & & 高山云雾林 & 热性高山云雾林 \\
\hline & & & 红树林 & $\begin{array}{l}\text { 真红树林 } \\
\text { 半红树林 } \\
\end{array}$ \\
\hline & & & 滨海(岛屿)沙生性丛林 & - \\
\hline & & & 滨江沙生性从林 & - \\
\hline & & & 竹林 & $\begin{array}{l}\text { 有刺竹林 } \\
\text { 无刺竹林 }\end{array}$ \\
\hline & \multirow[b]{2}{*}{ 灌从 } & \multirow[b]{2}{*}{ 阔叶灌丛 } & 地带性灌丛 & $\begin{array}{c}\text { 山顶灌从(高海拔原生灌丛) } \\
\text { 地带性次生灌丛 }\end{array}$ \\
\hline & & & 非地带性灌丛 & $\begin{array}{c}\text { 中山山顶灌从(中等海拔高度的山顶原生灌从) } \\
\text { 滨海(岛屿)沙生性灌丛 } \\
\text { 滨河、河口沙生性灌从 } \\
\text { 真红树林灌丛 } \\
\text { 半红树林灌丛 } \\
\end{array}$ \\
\hline & \multirow[b]{2}{*}{ 草丛 } & \multirow[b]{2}{*}{ 草丛 } & 地带性次生草丛 & $\begin{array}{l}\text { 禾草草丛 } \\
\text { 非禾草草丛 }\end{array}$ \\
\hline & & & 非地带性草丛 & $\begin{array}{c}\text { 海水湿生草丛(海草床) } \\
\text { 淡水湿生草丛 } \\
\text { 滨水(咸水、半咸水、淡水)湿生草丛 } \\
\text { 滨海(江河)沙生旱生性草丛 } \\
\text { 真红树林植物草丛 } \\
\text { 半红树林植物草丛 }\end{array}$ \\
\hline & \multirow{2}{*}{ 藤蔓丛 } & \multirow{2}{*}{ 藤蔓丛 } & 湿(水)生性藤蔓丛 & 淡水湿(水)生性藤蔓丛 \\
\hline & & & 旱生性藤蔓从 & 滨海、河口、潟湖、岛屿岸边的旱生性藤蔓丛 \\
\hline \multirow{9}{*}{ 人工植被 } & \multirow{3}{*}{ 生态防护植被 } & \multirow{3}{*}{ 生态防护植被 } & 防护林 & $\begin{array}{c}\text { 海防林 } \\
\text { 农耕地防护林 } \\
\text { 村庄防风林 } \\
\text { 保持水土林 } \\
\end{array}$ \\
\hline & & & 防护灌丛 & $\begin{array}{c}\text { 海防灌从 } \\
\text { 农耕地防护灌丛 } \\
\text { 防水土流失灌从 } \\
\text { 防眩光线灌从(在两侧反向高速公路中间种植) }\end{array}$ \\
\hline & & & 防护草丛 & 防水土流失草丛 \\
\hline & \multirow{3}{*}{ 生态景观植被 } & \multirow{3}{*}{ 生态景观植被 } & 庭院与公园植被 & $\begin{array}{l}\text { 单一优势种植被 } \\
\text { 混合优势种植被 }\end{array}$ \\
\hline & & & 道路生态景观植被 & 单一优势种植被 \\
\hline & & & $\begin{array}{c}\text { 森林旅游景区内生态景观 } \\
\text { 植被 } \\
\end{array}$ & - \\
\hline & \multirow{3}{*}{ 农业生产植被 } & \multirow{3}{*}{ 农业生产植被 } & 农作物 & $\begin{array}{l}\text { 水田农作物 } \\
\text { 旱地农作物 }\end{array}$ \\
\hline & & & 果园 & $\begin{array}{c}\text { 木本果园(林) } \\
\text { 草本果园 }\end{array}$ \\
\hline & & & 商品用材林 & $\begin{array}{c}\text { 竹林 } \\
\text { 非竹林 }\end{array}$ \\
\hline
\end{tabular}



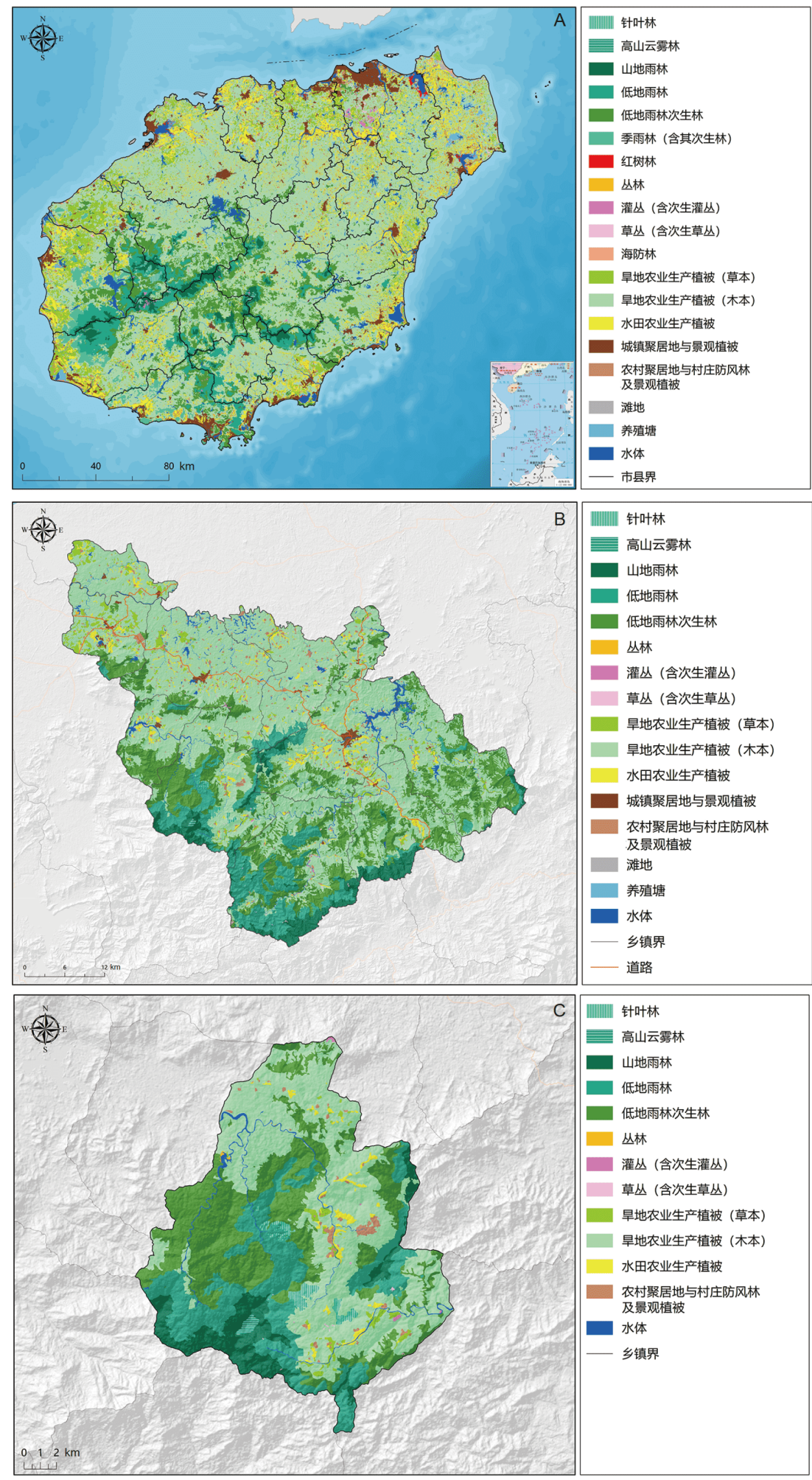

图 5 海南岛植被分布图与市县、乡镇植被分布图举例. A: 海南岛植被分布图; B: 白沙县植被分布图; C: 青松乡植被分布图

Figure 5 Distribution of vegetation types in Hainan Island and examples in counties and towns. A: Distribution of vegetation types in Hainan Island; B: distribution of vegetation types in Baisha county; C: distribution of vegetation types in Qingsong town 
然而, 不同的人研究的角度和范围不一样, 对海南 植被及热带森林的描述和植被类型的划分、命名有一 定的差异. 海南植被的分类目前属于百家争鸣阶段, 反 映不同学者所执的学术观点不同, 但这也产生学术上 和实践上的困扰和混淆. 这些争议在森林、灌从、草 从等多方面都存在. 在 《中国植被》 ${ }^{[3]}$ 中, 热带雨林、 季雨林是植被型，而山地雨林则作为热带雨林的植被 亚型. 《海南热带雨林》遵循这一学术观点 ${ }^{[7]}$, 但《广 东植被》 ${ }^{[39]}$ 以及王伯荪和张炜银 ${ }^{[29]}$ 将热带雨林、季 雨林、山地雨林作为植被型，《海南岛植被概要》 ${ }^{[42]}$ 中, 陈树培 ${ }^{[22]}$ 将雨林、季雨林作为植被型, 山地雨林 作为雨林的一个群系. 这些观点首先反映出不同学者 在对海南岛植被类型的分类等级上存在不同观点，特 别是在对季雨林这个植被类型的划分上存在的争议较 大. 中国植被编辑委员会 ${ }^{[3]}$ 和陈树培 ${ }^{[22]}$ 都把除海南岛 东南部之外的常绿林统称为“季雨林”(monsoon forests), 并进一步划分为“落叶季雨林” “半常绿季雨 林”(《中国植被》)或“常绿季雨林”等类型. 胡玉佳和 李玉杏 ${ }^{[7]}$ 较为全面地开展岛东南部吊罗山、西南部尖 峰岭、霸王岭和中部尖岭、卡法岭等的森林植被比较 研究, 认为在海南岛被称为“季雨林”的有些森林类型, 虽然有明显的干湿季, 但季雨林的特点不明显, 相反具 有较明显的雨林特征. 因此, 把热带常绿季雨林、沟谷 雨林称为热带雨林较为合适. 另外, 陈树培 ${ }^{[42]}$ 把乐东 县境内的中山地上部约海拔 1000 1200 m或 $1600 \mathrm{~m}$ 之 间的森林植被称为山地常绿阔叶林. 广东森林编辑委 员 ${ }^{[47]}$ 也采用这一名称，把海南岛热带山地常绿林和山 地常绿矮林作为常绿阔叶林植被型的植被亚型，后来 有些学者在保护区规划报告和植被研究中也沿用这一 名称 ${ }^{[49,50]}$. 但蒋有绪等人 ${ }^{[6]}$ 、胡玉佳和李玉杏 ${ }^{[7]}$ 却没有 用山地常绿阔叶林这一名称. 同是在乐东县, 《中国海 南岛尖峰岭热带林生态系统》一书, 把尖峰岭森林划 分为海拔 $1200 \mathrm{~m}$ 以上的称之为山顶苔藓矮林，海拔 $800 \sim 1000 \mathrm{~m}(1200 \mathrm{~m})$ 的森林称为热带山地雨林等. 有 些学者为了与亚热带常绿阔叶林有区别, 把这一类型 植被称为山地或山顶常绿林 ${ }^{[51]}$. 王伯荪和张炜银 ${ }^{[29]}$ 开 展了较详细的讨论, 把有争议的山地常绿阔叶林称为 山地常绿林, 区别于亚热带地区的常绿阔叶林. 本文 通过几十年的野外样地调查和认知, 结合海南的地形 地貌、气候(主要是干燥度)、土壤及样方数据的分析, 认为海南岛的植被, 在水平地带性方面只简单区分为
热带雨林和季雨林较为合适，在有垂直性差异的热带 低地雨林区, 垂直地带性方面区分为低地雨林、山地 雨林、高山云雾林和山顶灌从(图5).

灌从一直被植被生态学研究者忽视. 中国的灌丛 类型十分复杂, 在水平地带中并未占显著地位，但在 山地垂直带上常有灌从的原生性类型分布( 《中国资 源科学百科全书》 ${ }^{[52]}$. 在中国近代的植被生态研究的 文献中，用“灌从”或“灌草丛”较多，用灌丛林的较 少 ${ }^{[53]}$. 一般认为, 灌草丛多为灌丛受到破坏后退化形 成，或为草丛向灌从演替的过渡类型，或草丛有绝 对优势, 稀疏分布有灌木植株的类型 ${ }^{[54,55]}$. 但由于研 究资料较少, 相关的水平地带性分布的灌从，基本上 没有关注其起源, 《中国植被》 ${ }^{[3]}$ 对灌丛的划分也不 考虑其起源, 较多关注森林生态演替过程中次生灌从 的动态变化 ${ }^{[44,56 \sim 58]}$ 和生态服务功能 ${ }^{[59 \sim 61]}$. 海南的情况 与全国类似, 有待于进一步理清. 本文认为, 海南有地 带性的山顶灌从, 而非地带性有红树林中的一些灌 从、淡水湿地灌从、滨海(含海岛)沙生性灌从、滨江 (河)岸沙生性灌丛, 其他的是热带雨林或季雨林被破 坏后形成的次生灌从，按其起源的森林类型是地带性 植被类型, 固也称之为地带性次生灌从.

尽管《中国植被》 ${ }^{[3]}$ 把分布在海南西南部, 由稀 疏分布的木棉、厚皮树及较耐干旱的禾草构成的草从 植被划分成次生性稀疏草原, 但海南是否分布有稀树 草原及其形成的原因成为海南草丛植被的最大争议焦 点. 有的学者在进一步研究后认为, 近代人类活动干扰 是造成琼西南稀树草原生态环境的形成的原因. 李森 等人 ${ }^{[62]}$ 认同以上观点. 也有学者认为, 琼西地区热带 稀树草原的形成主要受气候条件的控制, 影响琼西地 区旱季气温和降水的东北向冬季风及干热风是决定该 地稀树草原的主要因素 ${ }^{[63]}$.

实际上，目前在西南部地区还分布有残存的季雨 林，如在东方大田坡鹿国家级自然保护区内，存有次 生季雨林. 自符国瑗 ${ }^{[64]}$ 报道后, 目前还有分布 ${ }^{[65]}$. 本文 认为, 海南不存在原生性的稀树草原, 除了一些水生 (湿生、半湿生)草丛外, 海南的绝大多数草丛基本上 是次生性草丛.

无论是早期出版的《广东植被》《中国植被》, 还是近期出版的其他地方植被，都没有给藤本植物为 优势的植被类型一个位置. 有研究报告过以藤本植物 为优势的植物群落(群系), 如厚藤群系 ${ }^{[66]}$ 、过江藤群 
系 ${ }^{[67]}$ ，但都归在草丛植被型组中．在海南的沿海沙地 植被类型中，把匍匐植物群落归为一个植被类型来表 述，但都归放在沿海砂生草从中. 能否在传统的森 林、灌从和草丛等植被型组中，加一个藤蔓从植被型 组，与森林、灌丛和草丛等植被型组并列呢？目前未 见报道. 由于藤蔓丛植物群落研究较少, 国内外相关 的植被分类体系中，似乎忽略了这一特殊的植被类型。 因此，在各个植被分类体系中找不到藤蔓从的“合法位 置”, 也正因如此, 又导致了相关学者对藤蔓丛群落研 究的忽视. 本文认为, 独立于其他植被类型分布的藤蔓 从是存在的. 在海南至少有两个藤蔓从植被型, 分别为 湿(水)生藤蔓从和分布在滨海、河口、潟湖和岛屿岸 边沙滩上的旱生性藤蔓从等.
到目前为止，人工植被还没有一个统一的分类体 系，如果分为农田植被和园林植被或只分为农村植被 和城市植被就太笼统 ${ }^{[3,28,68]}$. 本文在研究城市与农村的 人工植被分类基础上 ${ }^{[69 \sim 71]}$, 遵循以人工植被的应用功 能为分类原则, 在海南的人工植被分类系统里, 把海 南的人工植被主要分为生态防护植被、生态景观植被 和农业生产植被三大类型. 生态防护植被有防护林、 防护灌从和防护草从; 生态景观植被有庭院与公园生 态景观植被、道路生态景观植被和森林旅游景区(含 植物园)内生态景观植被; 农业生产植被有水生农业生 产植被和旱生农业生产植被, 后者又可细分为草本旱 生农业生产植被和木本旱生农业生产植被. 各类农业 生产植被由农作物、果园、商品用材林等构成.

\section{参考文献}

1 Richards P W. The Tropical Rain Forest. Cambridge: Cambridge University Press, 1952

2 Whitmore T C. Tropical Rain Forest of the Far East. Oxford: Clarendon Press, 1975

3 Vegetation of China Editorial Board. Vegetation of China (in Chinese). Beijing: Science Press, 1980 [中国植被编辑委员会. 中国植被. 北京: 科 学出版社, 1980]

4 Jin Z Z. Study on the basic characteristics of Yunnan tropical rain forest and monsoon rain forest (in Chinese). J Yunan Univ, 1983, (1 \& 2): 197207 [金振洲. 论云南热带雨林和季雨林的基本特征. 云南大学学报, 1983, (1 \& 2): 197-207]

5 Lu Y, Li M G, Huang Y W, et al. Vegetation of Bawangling Gibbon Natural Reserve in Hainan Island (in Chinese). Acta Phytoecol Geobot Sin, 1986, 10: 106-114 [陆阳, 李鸣光, 黄雅文, 等. 海南岛坝王岭长臂猿自然保护区植被. 植物生态学与地植物学学报, 1986, 10: 106-114]

6 Jiang Y X, Lu J P. Tropical Forest Ecosystem in Jianfengling, Hainan Island, China (in Chinese). Beijing: Science Press, 1991 [蒋有绪, 卢俊培. 中国海南岛尖峰岭热带林生态系统. 北京: 科学出版社, 1991]

7 Hu Y J, Li Y X. The Tropical Rain Forest of Hainan Island (in Chinese). Guangzhou: Guangdong Higher Education Press, 1992 [胡玉佳, 李玉 杏. 海南岛热带雨林. 广州: 广东高等教育出版社, 1992]

8 Li Y D. Community characteristics of tropical mountain rain forest in Jianfengling, Hainan Island (in Chinese). J Trop Subtrop Bot, 1997, 5: 1826 [李意德. 海南岛尖峰岭热带山地雨林的群落结构特征. 热带亚热带植物学报, 1997, 5: 18-26]

9 Zhu H. The tropical rain forest vegetation in Xishuangbanna (in Chinese). Trop Geogr, 1990, 10: 233-240 [朱华. 西双版纳的热带雨林植被. 热 带地理, 1990, 10: 233-240]

10 Zhu H, Zhou H Y. A comparative study on the tropical rain forests in Xishuangbanna and Hainan (in Chinese). Acta Bot Yunnan, 2002, 24: 1-13 [朱华, 周虹霞. 西双版纳热带雨林与海南热带雨林的比较研究. 云南植物研究, 2002, 24: 1-13]

11 Yang X B, Wu Q S, Li D H, et al. Research on Forest Vegetation of National Forest Ecosystem Nature Reserve in Hainan Island (in Chinese). Beijing: Science Press, 2011 [杨小波, 吴庆书, 李东海, 等. 海南岛陆域国家级森林生态系统自然保护区森林植被研究. 北京: 科学出版社, 2011]

12 Yang X B, Chen Z Z, Li D H, et al. Vegegraphy of Hainan (V1) (in Chinese). Beijing: Science Press, 2019 [杨小波, 陈宗铸, 李东海, 等. 海南植 被志(第一卷). 北京: 科学出版社, 2019]

13 Beard J S. The classification of tropical American vegetation-types. Ecology, 1955, 36: 89-100

14 Quigley M F, Platt W J. Composition and structure of seasonally deciduous forests in the Americas. Ecol Monogr, 2003, 73: 87-106

15 Bullock S H, Medina E. Introduction. In: Bullock S H, Mooney H A, Medina E, eds. Seasonally Dry Tropical Forests. Cambridge: Cambridge University Press, 1995. 1-8

16 Lott E J, Bullock S H, Solis-Magallanes J A. Floristic diversity and structure of upland and arroyo forests of coastal Jalisco. Biotropica, 1987, 19: 
$228-235$

17 Davidar P, Puyravaud J P, Leigh E G. Changes in rain forest tree diversity, dominance and rarity across a seasonality gradient in the Western Ghats, India. J Biogeogr, 2005, 32: 493-501

18 Webb L J, Tracey J G, Williams W T. The value of structural features in tropical forest typology. Aust J Ecol, 1976, 1: 3-28

19 Webb L J. A general classification of Australian rainforest. Australian Plants, 1978, 9: 349-363

20 Whitmore T C. An Introduction to Tropical Rainforest. 2nd ed. Oxford: Oxford University Press, 1998

21 Comprehensive Investigation Team of Tropical Agriculture Zoning in Hainan Island. Hainan Island Agricultural Regionalization Report Collection (in Chinese). (internal documents), 1981 [海南岛热带农业区划综合考查队. 海南岛农业区划报告集. (内部资料), 1981]

22 Guangzhou Institute of Geography. Tropical Agriculture Natural Resources and Regionalization in Hainan Island (in Chinese). Beijing: Science Press, 1985 [广州地理研究所. 海南岛热带农业自然资源与区划. 北京: 科学出版社, 1985]

23 Hainan Provincial Chronicles Office. Hainan Provincial Chronicles-Physical Geography (in Chinese). Haikou: Hainan Publishing House, 2011 [海南省地方志办公室. 海南省志一一自然地理志. 海口: 海南出版社, 2011]

24 Hainan Yearbook Editorial Committee. Hainan Yearbook (in Chinese). Haikou: Hainan Yearbook Press, 2010 [《海南年鉴》编辑委员会. 海南 年鉴. 海口: 海南年鉴社, 2010]

25 Chen Z C, Zhao W J, Gong Z T. Correlation of soil taxa of Hainan Island between Chinese soil genetic classification and Chinese soil taxonomy (in Chinese). Acta Pedol Sin, 2003, 40: 170-177 [陈志诚, 赵文君, 龚子同. 海南岛土壤发生分类类型在系统分类中的归属. 土壤学报, 2003, 40: $170-177]$

26 Gong Z T, Zhang G L, Qi Z P. Introduction to Soil System of Hainan Island (in Chinese). Beijing: Science Press, 2004 [龚子同, 张甘霖, 漆智平. 海南岛土系概论. 北京: 科学出版社, 2004]

27 Wu Z Y. the Areal-type of Chinese genera of seed plants (in Chinese). Acta Bot Yunnan, 1991, 13: 1-139 [吴征镒. 中国种子植物属的分布区类 型. 云南植物研究, 1991, 13: 1-139]

28 Wang B S. Plant Community (in Chinese). Beijing: Higher Education Press, 1987 [王伯䔉. 植物群落学. 北京: 高等教育出版社, 1987]

29 Wang B S, Zhang W Y. The groups and features of tropical forest vegetation of Hainan Island (in Chinese). Guihuaia, 2002, 22: 107-115 [王伯 荪, 张炜银. 海南岛热带森林植被的类群及其特征. 广西植物, 2002, 22: 107-115]

30 Song Y C. 2011. Recognition and proposal on the vegetation classification system of China (in Chinese). Chin J Plant Ecol, 2011, 35: 882-892 [宋永昌. 对中国植被分类系统的认知和建议. 植物生态学报, 2011, 35: 882-892]

31 Song Y C. Ebergreen Broad-leaved Forest in China Classification-Ecology-Conservation (in Chinese). Beijing: Science Press, 2013 [宋永昌. 中 国常绿阔叶林: 分类、生态、保育. 北京: 科学出版社, 2013]

32 Fang J Y, Wang G H. Vegegraphy of China: surveying and describing the country’s vegetation. Chin J Plant Ecol, 2020, 44, 93-95. [方精云, 王国 宏. 《中国植被志》: 为中国植被登记造册. 植物生态学报, 2020, 44, 93-95]

33 Wang B S. Approach to the horizontal zonation of monsoon forests (in Chinese). Acta Phytoecol Geobot Sin, 1987, 11: 154-158 [王伯荪. 论季雨 林的水平地带性. 植物生态学与地植物学学报, 1987, 11: 154-158]

34 Chen H Y. Flora of Hainan Volume 1-4 (in Chinese). Beijing: Science Press, 1964-1977 [陈焕镛. 海南植物志1-4卷. 北京: 科学出版社, 19641977]

35 Xing F W, Zhou J S, Wang F G, et al. Inventory of Plant Species Diversity of Hainan (in Chinese). Beijing: Huazhong University of Science and Technology Press, 2012 [邢福武, 周劲松, 王发国, 等. 海南植物物种多样性编目. 北京: 华中科技大学出版社, 2012]

36 Zhang H D. Vegetation of Paracel Islands (in Chinese). Acta Bot Sin, 1974, 16: 180-190 [张宏达. 西沙群岛的植被. 植物学报, 1974, 16: 180190]

37 Hou K Z, Xu X H. Plants and Vegetation of Hainan Island and General Situation of Vegetation of Guangdong Mainland (in Chinese). Beijing: Science Press, 1955 [侯宽昭, 徐祥浩. 海南岛的植物和植被与广东大陆植被概况. 北京: 科学出版社, 1955]

38 Zhang H D. Vegetation classification scheme of Hainan Island (in Chinese). Acta Phytoecol Geobot Sin, 1963, Z1: 141 [张宏达. 海南岛的植被 分类方案. 植物生态学与地植物学丛刊, 1963, Z1: 141]

39 Guangdong Institute of Botany. Guangdong Vegetation (in Chinese). Beijing: Science Press, 1976 [广东省植物研究所. 广东植被. 北京: 科学出 版社, 1976]

40 Hu W Y. The vegetation belts and forest types of Jianfengling Mountain, Hainan Island (in Chinese). Acta Phytoecol Geobot Sin, 1985, 9: 286296 [胡婉仪. 海南岛尖峰岭的植被垂直带及林型. 植物生态学与地植物学丛刊, 1985, 9: 286-296] 
41 Huang Q, Li Y D, Zheng D Z, et al. Study of tropical vegetation series in Jianfengling Region, Hainan Island (in Chinese). Acta Phytoecol Geobot Sin, 1986, 10: 90-105 [黄全, 李意德, 郑德璋, 等. 海南岛尖峰岭地区热带植被生态系列的研究. 植物生态学与地植物学学报, 1986, 10: 90-105]

42 Chen S P. Overview of the vegetation of Hainan Island (in Chinese). Ecol Sci, 1982, 1: 29-37 [陈树培. 海南岛的植被概要. 生态科学, 1982, 1: 29-37]

43 Jiang Y X. A background analysis of the flora and the characteristics of tropical vegetationin Hainan Island (in Chinese). Nat Sci J Hainan Univ, 1988, 6: 1-8 [蒋有绪. 海南岛植物区系与热带植被性质的背景分析. 海南大学学报(自然科学版), 1988, 6: 1-8]

44 Yang X B, Zhang T L, Wu Q S. The relationship between biodiversity and soil fertility chara-cteristics on abandoned fields in the tropical region of southern China andoned field, Hainan Island (in Chinese). Acta Ecol Sin, 2002, 22: 190-196 [杨小波, 张桃林, 吴庆书. 海南琼北地区不同植 被类型物种多样性与土壤肥力的关系. 生态学报, 2002, 22: 190-196]

45 Liu W D. Community ecology of tropical monsoon rainforest in Hainan Island, China (in Chinese). Dissertation for Doctoral Degree. Beijing: Chinese Academy of Forestry, 2009 [刘万德. 海南岛热带季雨林群落生态学研究. 博士学位论文. 北京: 中国林业科学研究院, 2009]

Hou X Y. Flora of China (in Chinese). Beijing: People's Education Press, 1960 [侯学显. 中国的植被. 北京: 人民教育出版社, 1960]

47 Guangdong Forest Editor Committee. Guangdong Forest (in Chinese). Beijing: China Forestry Press, 1990 [广东森林编辑委员会. 广东森林. 北 京: 中国林业出版社, 1990]

48 China Forest Editor Committee. Forest of China (V3) (in Chinese). Beijing: China Forestry Press, 1999 [中国森林编辑委员会. 中国森林(第三 卷). 北京: 中国林业出版社, 1999]

49 Ding T, Liao W B, Jin J H, et al. Floristic analysis on the seed plant of Mt. Diaoluo in Hainan Island (in Chinese). Guihaia, 2002, 22: 311-319 [丁 坦, 廖文波, 金建华, 等. 海南岛吊罗山种子植物区系分析. 广西植物, 2002, 22: 311-319]

50 Huang K Y, Liao W B, Jin J H. Analysis of plant community characteristics and diversity of Diaoluo Mountain, Hainan Island (in Chinese). Ecol Environ, 2007, 16: 900-905 [黄康有, 廖文波, 金建华. 海南岛吊罗山植物群落特征和物种多样性分析. 生态环境, 2007, 16: 900-905]

51 Fu G A. A Preliminary report of investigation regarding vegetation of Natural Reserve of Natural Reserve of Tiaolo-Mountain (in Chinese). Ecol Sci, 1991, 1: 46-55 [符国瑗. 吊罗山自然保护区植被调查. 生态科学, 1991, 1: 46-55]

52 Editorial Committee of Encyclopedia of Chinese Resources Science. Encyclopedia of Chinese Resources Science (in Chinese). Dongying: Petroleum University Press, 2000 [中国资源科学百科全书编辑委员会. 中国资源科学百科全书. 东营: 石油大学出版社, 2000]

53 Geng Y Q, Yu X X, Sun X Y, et al. Characteristics of soil fertility under pure Pinus and shrubs in Badaling Mountain area of Beijing (in Chinese). J Beijing Forest Univ, 2007, 29: 50-54 [耿玉清, 余新晓, 孙向阳, 等. 北京八达岭地区油松与灌丛林土壤肥力特征的研究. 北京林业大学学 报, 2007, 29: 50-54]

54 Jin Z Z. The characteristics and utilization of shrub-grasslands in tropical and substropical mountains of Yunnan (in Chinese). Acta Phytoecol Geobot Sin, 1986, 10: 81-89 [金振洲. 云南热带、亚热带山地灌草丛植被特点及利用途径. 植物生态学与地植物学学报, 1986, 10: 81-89]

55 Luo G T, Ye Y Q. Characteristics and distribution of shrub, shrub-herbosa and mountainous herbosa-meadow in Quanzhou, Fujian (in Chinese). Subtrop Plant Res Commun, 1995, 24: 39-46 [罗光坦, 叶友谦. 泉州灌从、灌草丛和山地草丛草甸的特征与分布. 亚热带植物通讯, 1995, 24: $39-46]$

56 Jia Z Q, Li C Z, Liu C M. Study of the correlation and succession law of natural secondary shrubs and ecological environment factors in the rocky sandstone area of Taihang Mountain (in Chinese). J Beijing Forest Univ, 1996, 18: 17-23 [贾志清, 李昌哲, 刘创民. 太行山石质砂岩区天然次 生灌木林与生态环境因子相关性及其演替规律的研究. 北京林业大学学报, 1996, 18: 17-23]

57 Yang X B, Wu Q S. Vegetation development on tropical abandoned fields, Hainan Island, China (in Chinese). Chin J Plant Ecol, 2000, 24: 477482 [杨小波, 吴庆书. 海南岛热带地区弃荒农田次生植被恢复特点. 植物生态学报, 2000, 24: 477-482]

58 Zhou W, Long C, Yang X B, et al. the Thinning regular of the shrubbery at Tongguling National Nature Reserve on Hainan Island, China (in Chinese). Acta Ecol Sin, 2013, 33: 6569-6576 [周威, 龙成, 杨小波, 等. 海南铜鼓岭灌木林稀疏规律. 生态学报, 2013, 33: 6569-6576]

59 Yu H S, Li B J, Zhang B W, et al. Main ecological role of shrub forest (in Chinese). Inner Mongol Forest Sci Technol, 2003, 4: 15-18 [俞海生, 李 宝军, 张宝文, 等. 灌木林主要生态作用的探讨. 内蒙古林业科技, 2003, 4: 15-18]

60 Xu Q F, Jiang P K, Shen Q. Comparison of organic carbon pool of soil in bush and broad-leaved forests (in Chinese). J Beijing Forest Univ, 2005, 27: 18-22 [徐秋芳, 姜培坤, 沈泉. 灌木林与阔叶林土壤有机碳库的比较研究. 北京林业大学学报, 2005, 27: 18-22]

61 Shang S Y, Li Y F, Jiang P K, et al. Effects of the conversion from native shrub forest to Chinese chestnut plantation on soil carbon and nitrogen pools (in Chinese). Chin J Appl Ecol, 2012, 23: 659-665 [商素云, 李永夫, 姜培坤, 等. 天然灌木林改造成板栗林对土壤碳库和氮库的影响. 
应用生态学报, 2012, 23: 659-665]

62 Li S, Sun W, Li F, et al. Study on the characteristics and the cause of sandy desertified land in the West of Hainan Island (in Chinese). Acta Geogr Sin, 2005, 60: 433-444 [李森, 孙武, 李凡, 等. 海南岛西部热带沙漠化土地特征与成因. 地理学报, 2005, 60: 433-444]

63 Ou X J, Zeng L H, Lin P S, et al. Preliminary study on the origin of savanna in Western Hainan Island (in Chinese). J Arid Land Resour Environ, 2013, 27: 45-53 [欧先交, 曾兰华, 林培松, 等. 琼西热带稀树草原成因初探. 干旱区资源与环境, 2013, 27: 48-53]

$64 \mathrm{Fu} \mathrm{G} \mathrm{A.} \mathrm{A} \mathrm{preliminary} \mathrm{report} \mathrm{of} \mathrm{investigation} \mathrm{regarding} \mathrm{vegetation} \mathrm{of} \mathrm{rare} \mathrm{animals} \mathrm{reserve} \mathrm{in} \mathrm{Datian} \mathrm{of} \mathrm{Hainan} \mathrm{Island} \mathrm{(in} \mathrm{Chinese).} \mathrm{Acta}$ Phytoecol Geobot Sin, 1986, 10: 153-155 [符国瑗. 海南岛大田坡鹿保护区植被调查初报. 植物生态学与地植物学学报, 1986, 10: 153-155]

$65 \mathrm{Lu}$ X L, Yuan X C, He B, et al. Vegetation cover changes of habitats of Hainan Eld's Deer (in Chinese). Sichuan J Zool, 2008, 27: 675-679 [卢学 理, 袁喜才, 何兵, 等. 海南坡鹿栖息地植被覆盖变化研究. 四川动物, 2008, 27: 675-679]

66 Li X X. Types, distribution and evolution of sandy vegetation along coasts in Guangxi (in Chinese). J Guangxi Acad Sci, 2005, 21: 27-36 [李信 贤. 广西海岸沙生植被的类型及其分布和演潜. 广西科学院学报, 2005, 21: 27-36]

67 Liang S C. Classification system of wetland vegetation in Guangxi (in Chinese). Guihaia, 2011, 31:47-51 [梁士楚. 广西湿地植被分类系统. 广 西植物, 2011, 31: 47-51]

68 Su Z M, Li X K, Ding T, et al. The Vegetation of Guangxi (in Chinese). Beijing: China Forestry Press, 2014 [苏宗明, 李先琨, 丁涛, 等. 广西植 被志. 北京: 中国林业出版社, 2014]

69 Yang X B. Rural Ecology (in Chinese). Beijing: China Agriculture Press, 2008 [杨小波. 农村生态学. 北京: 中国农业出版社, 2008]

70 Yang X B. Urban Plant Diversity (in Chinese). Beijing: China Agriculture Press, 2009 [杨小波. 城市植物多样性. 北京: 中国农业出版社, 2009]

71 Yang X B. Urban Ecology (in Chinese). Beijing: Science Press, 2014 [杨小波. 城市生态学. 北京: 科学出版社, 2014]

\title{
Classification and distribution of vegetation in Hainan, China
}

\author{
YANG XiaoBo ${ }^{1}$, CHEN ZongZhu ${ }^{1,2} \&$ LI DongHai ${ }^{1}$ \\ 1 College of Ecology and Environment, Hainan University, Haikou 570028, China; \\ 2 Hainan Academy of Forestry, Haikou 571199, China
}

In this paper, we analyzed the composition and structural characteristics of the vegetation of Hainan based on historical data and extensive field surveys conducted for more than 30 years. The vegetation classification system is revised and improved, and the vegetation is mapped through remote sensing interpretation and field data. The results reveal the following: (i) the Hainan vegetation can be divided into two types of rain forest areas, tropical and seasonal, in terms of horizontal zonality. The vegetation can be further divided into lowland and mountain rain forests as well as mountain cloud forest and mountain shrub in the tropical rain forest area. However, the vertical heterogeneity of the vegetation types is not obvious in the seasonal rain forest area. (ii) A significant number of vegetation types belonging to the a-zonal vegetation include sea-grass beds (grass), mangrove and coastal jungles (including the Island jungle of Sansha city), riverside jungles, secondary grass, secondary bush and vine bush, etc. The vegetation of Hainan can also be divided into natural and artificial. The natural vegetation forms four classes of vegetation types: forest, shrub, grass, and vine, composed of five vegetation formation (vegetation formation=vegetation-type in Vegetation of China) groups, 14 vegetation formations and 196 alliances (alliances=formation in Vegetation of China, and group in Vegegraphy of Hainan). The artificial vegetation can be divided into three vegetation-type classes: ecological protection, ecological landscape, and agricultural production vegetation, containing nine vegetation types. The vegetation of Hainan has been mapped (excluding the vegetation of Sansha city) with a resolution that meets the requirements at a scale of 1:50000.

vegetation classification, tropical vegetation, Hainan, China, vegetation mapping

doi: $10.1360 /$ SSV-2020-0286 